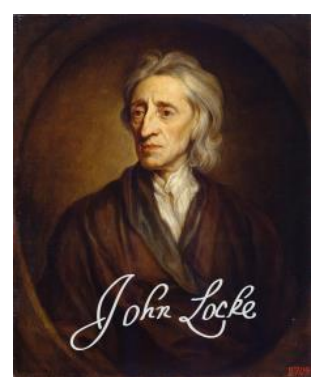

LOCKE STUDIES

Vol. 16

https://doi.org/10.5206/ls.2016.648 | ISSN: 1476-0290

Originally published: 2016

Published online: 08 February 2018

(c) Locke Studies, 2016

\title{
The Role of Appropriation in Locke's Account of Persons and Personal Identity
}

\author{
RUTH BOEKER (UNIVERSITY COLLEGE DUBLIN)
}

Recommended citation:

Boeker, Ruth. "The Role of Appropriation in Locke's Account of Persons and Personal Identity." Locke Studies 16 (2016): 3-39. https://doi.org/10.5206/ls.2016.648

For more information about this article:

https://ojs.lib.uwo.ca/index.php/locke/article/view/648

Locke Studies is published by The John Locke Society.

This is an open access article published under the terms of the Creative Commons AttributionNonCommercial-ShareAlike 4.0 International license, which permits use, distribution and reproduction in any medium, provided the original work is properly cited and shared under the original license. 


\title{
THE ROLE OF APPROPRIATION IN LOCKE'S ACCOUNT OF PERSONS AND PERSONAL IDENTITY
}

\author{
RUTH BOEKER
}

\begin{abstract}
According to Locke, appropriation is a precondition for moral responsibility and thus we can expect that it plays a distinctive role in his theory. Yet it is rare to find an interpretation of Locke's account of appropriation that does not associate it with serious problems. To make room for a more satisfying understanding of Locke's account of appropriation we have to analyse why it was so widely misunderstood. The aim of this paper is fourfold: First, I will show that Mackie's and Winkler's interpretations that have shaped the subsequent discussion contain serious flaws. Second, I will argue that the so-called appropriation interpretation - that is the view that appropriation is meant to provide alternative persistence conditions for persons-lacks support. Third, I will re-examine Locke's texts and argue that we can come to a better understanding of his notion of appropriation in the Essay if we interpret it in analogy to his account of appropriation in Two Treatises. Fourth, I will offer a more fine-grained interpretation of the role of appropriation in relation to persistence conditions for persons. I conclude by showing that the advantage of this proposal is that it reconciles interpretations that have commonly been thought to be inconsistent.
\end{abstract}

Keywords: John Locke, appropriation, person, personal identity, consciousness

\section{\$1. Introduction}

Locke's theory of personal identity aims to answer questions of moral accountability. For Locke it is important that a person understands why he or she is held accountable for an action and this involves that he or she understands the moral laws and appropriates the action, or acknowledges it as his or her own. This means that, according to Locke, appropriation is a precondition for moral accountability and we can therefore expect that appropriation plays a distinctive role in Locke's theory (see II.xxvii.16, 26). ${ }^{1}$

${ }^{1}$ All references to John Locke, An Essay concerning Human Understanding, ed. Peter H. Nidditch (Oxford, 1975), will appear by book number, chapter number, and section number. For further discussion see Antonia LoLordo, Locke's Moral Man (Oxford, 2012), ch. 2; J. L. Mackie, Problems from Locke (Oxford, 1976), 176-77, 183; Galen Strawson, Locke on Personal Identity: Consciousness and Concernment 
Despite the significance of appropriation, the reception of it in the literature is predominantly dismissive or negative, and it is rare to find an interpretation that does not associate appropriation with serious problems for Locke's theory. ${ }^{2}$ In this paper I will argue that a satisfying interpretation of Locke's account of appropriation is missing and that the arguments that are meant to present problems for Locke's account of appropriation are seriously flawed. By analyzing why Locke's account of appropriation has been so widely misunderstood, I want to urge all those interpreters who tend to assume that Locke's notion of appropriation is well explored and understood in the literature to re-examine Locke's actual views. ${ }^{3}$

In the literature J. L. Mackie and Kenneth Winkler are often given credit for drawing attention to appropriation. ${ }^{4}$ However, Mackie associates appropriation with 'perhaps the most damaging objection' 5 against Locke's theory of personal identity, and Winkler ends his interpretation by acknowledging a tension between Locke's account of appropriation and divine

(Princeton, NJ, 2011), ch. 3, especially 17-18; Kenneth P. Winkler, 'Locke on Personal Identity', Journal of the History of Philosophy 29 (1991): 223; Gideon Yaffe, 'Locke on Ideas of Identity and Diversity', in The Cambridge Companion to Locke's "Essay concerning Human Understanding”, ed. Lex Newman (Cambridge, 2007), 220-23.

${ }^{2}$ See Mackie, Problems from Locke, 183; Shelley Weinberg, 'Locke on Personal Identity', Philosophy Compass 6 (2011): 401-2 and 'The Metaphysical Fact of Consciousness in Locke's Theory of Personal Identity', Journal of the History of Philosophy 50 (2012): 388-90; Winkler, 'Locke on Personal Identity'; Yaffe, 'Locke on Ideas of Identity and Diversity', 221-23. LoLordo, Locke's Moral Man, ch. 2, does not follow the negative trend and endorses an appropriation interpretation. Other interpreters, who acknowledge appropriation in Locke's theory, but who are less often cited, include Michael Ayers, Locke: Epistemology and Ontology (2 vols., London, 1991), ii, 266-68; David P. Behan, 'Locke on Persons and Personal Identity', Canadian Journal of Philosophy 9 (1979): 53-75; Eric Matthews, 'Descartes and Locke on the Concept of a Person', The Locke Newsletter 8 (1977): 26-28, 32-33; Strawson, Locke on Personal Identity, 17-18; Udo Thiel, Lockes Theorie der personalen Identität (Bonn, 1983), 116-17.

${ }^{3}$ For example, LoLordo, Locke's Moral Man, maintains that ' $[\mathrm{t}]$ he appropriation interpretation is relatively familiar' (66).

${ }^{4}$ See Mackie, Problems from Locke, 183; Winkler, 'Locke on Personal Identity'.

${ }^{5}$ Mackie, Problems from Locke, 183. 
rectification. In the recent literature there has been a revival of this discussion, and Gideon Yaffe, Shelley Weinberg, and Antonia LoLordo have coined the term 'appropriation interpretation. $^{6}$ While they all ascribe this interpretation to Winkler - and in some degree to Mackie - they tend to assume that appropriation is meant to provide alternative persistence conditions for persons that avoid problems that arise for memory interpretations, namely, the view that (direct or indirect) memory relations are necessary and sufficient for personal identity. ${ }^{7}$ This means the appropriation interpretation is the view that the necessary and sufficient conditions of what makes a person the same over time are to be understood in terms of appropriation. It is not obvious that Winkler's original interpretation actually supports this view and thus I will use the term 'appropriation interpretation' to refer to the view that appropriation is meant to

${ }^{6}$ See LoLordo, 'Author Meets Critics on Antonia LoLordo's "Locke's Moral Man": LoLordo's Reply to Weinberg', The Mod Squad: A Group Blog in Modern Philosophy, June 25, 2014, http://philosophymodsquad.wordpress.com/2013/07/07/amc-lmmlolordos-reply-to-weinberg/, Locke's Moral Man, ch. 2, especially 65-66, 70-74, 82 (n 30), 98-99, 102; Shelley Weinberg, 'Author Meets Critics on Antonia LoLordo's "Locke's Moral Man": Shelley Weinberg', The Mod Squad, June 25, 2014, http://philosophymodsquad.wordpress.com/2013/07/06/amc-lmm-shelley-weinberg/

'Locke on Personal Identity', 401-2, 'The Metaphysical Fact', 388-90; Yaffe, 'Locke on Ideas of Identity and Diversity', 221-23.

${ }^{7}$ Yaffe argues that, according to Locke, personal identity consists in sameness of consciousness and so the real question is what Locke means by sameness of consciousness. Yaffe discusses different meanings of sameness of consciousness. After he has outlined the problems for the view that consciousness is to be understood in terms of memory, he turns to the proposal that "consciousness" is to be understood as "appropriation" or "subjective constitution" ('Locke on Ideas of Identity and Diversity', 221). This set-up makes clear that he assumes appropriation is meant to provide alternative persistence conditions for persons. Similarly Weinberg considers problems concerning the memory and appropriation interpretations to motivate her own interpretation of Locke's persistence conditions for persons. See 'Locke on Personal Identity', 401-2, 'The Metaphysical Fact', 388-90. LoLordo asks how consciousness extends itself backwards. She rejects the view that consciousness extends itself by memory in favour of her view that it extends itself by appropriation (see Locke's Moral Man, 65, 70, 73). LoLordo argues 'that consciousnesses extend themselves into the past and future by appropriation' (Locke's Moral Man, 65). The phrase 'consciousness extends itself by appropriation' is vague, but because LoLordo contrasts her view with the memory interpretation she seems to treat appropriation as analogous to memory relations. 
provide persistence conditions for persons, but, contrary to Yaffe, Weinberg, and LoLordo, I will examine whether, rather than assume that, Winkler endorses it. Moreover, it is not obvious that Locke would endorse it either. If this was his view, why did he not simply say that personal identity consists in appropriation, rather than claiming that it consists in sameness of consciousness? Yaffe and Weinberg acknowledge the appropriation interpretation as an important interpretation, but argue that their own respective interpretations of the persistence conditions for persons are to be preferred and not subject to the problems associated with the appropriation interpretation. All those who follow the trend and associate persistence conditions in terms of appropriation with serious problems tend to dismiss the possibility that appropriation can play a different role in Locke's theory. ${ }^{8}$ In contrast to Yaffe and Weinberg, LoLordo endorses the appropriation interpretation.

The aim of this paper is fourfold: First, I will carefully examine Mackie's and Winkler's influential interpretations and show that their arguments, which are meant to present problems for Locke's account of appropriation, are seriously flawed. Second, I will argue that the so-called appropriation interpretation lacks support, because it cannot be ascribed to Mackie and Winkler as is assumed by Yaffe, Weinberg, and LoLordo and that the problems that Yaffe and Weinberg associate with it dissolve under closer scrutiny. Third, I will re-examine Locke's texts and argue that we can come to a better understanding of his account of appropriation in the Essay if we interpret it in analogy to his account of appropriation in Two Treatises. Fourth, I will offer a more fine-grained interpretation of the role of appropriation in relation to persistence conditions for persons. I will propose that we can make progress by considering separately the relations and the relata that compose persistence conditions. Given this distinction, I argue that it is plausible that the relevant relata are

${ }^{8} \mathrm{I}$ admit that it is not the central task of Yaffe's and Weinberg's papers to offer a theory of appropriation, but the predominantly negative treatment of appropriation in the literature may explain why so few interpreters offer positive interpretations of it. 
appropriated actions or thoughts, ${ }^{9}$ but that it is hard to make sense of the view that appropriation provides alternative relations that constitute the persistence conditions. These distinctions enable me to show that it is misleading to present the appropriation interpretation as an alternative to the memory interpretation, but rather, if we accept my proposed distinctions, appropriation can be reconciled with psychological interpretations as well as with interpretations such as Weinberg's that argue for a more robust metaphysical fact of consciousness. ${ }^{10}$ The advantage of my proposal is that it does not dismiss appropriation as the critics of the appropriation interpretation do, but instead acknowledges that appropriation plays a distinctive role in Locke's theory and takes seriously the questions of moral accountability that are at the heart of Locke's theory.

\section{\$2. Mackie on Appropriation}

Let us turn to J. L. Mackie's influential discussion in Problems from Locke. He emphasizes that Locke's theory is a theory of action appropriation, but regards this to be an objection against Locke's theory:

$[\mathrm{P}]$ erhaps the most damaging objection is this. Since a man at $t_{2}$ commonly remembers only some of his experiences and actions at $t_{l}$, whereas what constituted a person at $t_{1}$ was all the experiences and actions that were then co-conscious, Locke's view fails to equate a person identified at $t_{2}$ with any person identifiable at $t_{1}$. It is only a theory of how some items which belonged to a person identifiable at $t_{1}$ are appropriated by a person who can

${ }^{9}$ It is worth noting that Locke's term 'thought' is broader than it is in present-day usage and includes any conscious mental state. He adopts this broad notion from his predecessors Descartes and Cudworth. See Keith Allen, 'Cudworth on Mind, Body, and Plastic Nature', Philosophy Compass 8 (2013): 337-47, 343.

${ }^{10}$ See Weinberg, 'The Metaphysical Fact'.

11 For further discussion see Ruth Boeker, 'The Moral Dimension in Locke's Account of Persons and Personal Identity', History of Philosophy Quarterly 31 (2014): 229-47; Edmund Law, 'A Defence of Mr. Locke's Opinion Concerning Personal Identity', in vol. 2 of The Works of John Locke, 12th ed. (London, 1824); Jessica Spector, 'The Grounds of Moral Agency: Locke's Account of Personal Identity', Journal of Moral Philosophy 5 (2008): 256-81. 
be identified as such only at $t_{2}$. It is therefore hardly a theory of personal identity at all, but might be better described as a theory of action appropriation. Locke seems to be forgetting that 'person' is not only 'a forensic term, appropriating actions and their merit', but also the noun corresponding to all the personal pronouns. (Problems from Locke, 183)

Mackie distinguishes a theory of personal identity from a theory of action appropriation. In order to explain his argument, it is worth specifying what he means by each of them respectively.

A theory of personal identity offers necessary and sufficient conditions for a person $P_{1}$ existing at $t_{1}$ to be the same person as a person $P_{2}$ existing at $t_{2}$. The important point for Mackie's argument is that a theory of personal identity concerns individuals existing at different times. In contrast to this, according to Mackie, a theory of action appropriation offers an account of the actions that a being ${ }^{12}$ ascribes, or appropriates, to him- or herself at a particular time.

On this basis, we can analyze Mackie's argument for the claim that a theory of action appropriation does not qualify as a theory of personal identity. His argument has the following structure:

(1) A person at a time $t$ is constituted by all the experiences and actions of which he or she is co-conscious at $t$.

(2) A person $P_{2}$ at $t_{2}$ appropriates only some experiences and actions of a person $P_{l}$ existing at an earlier time $t_{1}$.

(3) In order for action appropriation to provide a suitable account of personal identity, $P_{2}$ has to appropriate all of $P_{1}$ 's experiences and actions.

(4) Action appropriation does not provide a suitable account of the identity of $P_{1}$ with $P_{2}$.

${ }^{12}$ I use the term 'being' to be neutral with respect to the question whether a person exists prior to the act of action appropriation or whether action appropriation is a constitutive element of a person's existence.

${ }^{13}$ The textual evidence is not decisive whether Locke intends to offer a theory of action appropriation or a theory of personal identity over time. Support for the former can be found in II.xxvii.16 and 26. However, other passages such as II.xxvii.25 suggest that, according to Locke, a person exists over time. 
The textual support makes it plausible to assume (1), and (2) is confirmed by experience. However, the question arises as to why Mackie endorses (3) and whether (3) should be accepted.

First, it is worth noting that (3) assumes that action appropriation is intended to provide persistence conditions for persons without providing any argument for this assumption. Second, Mackie equates the appropriation of a past action with remembering the past action as one's own. There are three different ways to interpret what is meant by appropriation of past actions by remembrance. ${ }^{14}$ First, to appropriate a past action could be understood simply as remembering that action. This reading reduces appropriation of past actions to memory. However, if this was correct, then appropriation would not play any distinctive role in Locke's theory and Mackie's interpretation would be a version of a psychological account of personal identity. ${ }^{15}$

Second, appropriation of past actions by remembrance could be a special kind of remembering that differs intrinsically from other kinds of memory. However, it is unlikely that Mackie understands appropriation in this sense, because it undermines his argument. Mackie assumes that in order for action appropriation to provide persistence conditions for persons, $P_{2}$ has to appropriate all the experiences and actions that $P_{1}$ was coconscious at $t_{l}$ and not merely those that one remembers in a special way.

On a third reading, appropriation of past actions could be distinguished from remembrance simpliciter, by proposing that appropriation does not only involve remembrance, but additionally a further component that cannot be reduced to

${ }^{14}$ Note that I here focus on the appropriation of past actions, since they are the focus of Mackie's argument. It is plausible that not only past actions are appropriated, but also present actions and the appropriation of present actions will involve consciousness, rather than memory. The considerations given here can be extended to the appropriation of present actions by replacing 'memory' with 'consciousness'.

${ }^{15}$ I use the term 'psychological account of personal identity' to refer to any theory that accounts for the persistence conditions for persons in terms of psychological relations such as consciousness or memory. 
memory. For instance, it can be suggested that appropriation of past actions, does not merely require that I remember the action, but, additionally, I must have performed the action. This proposal provides a means to distinguish my actions from the actions of others that I can remember or be aware of. While I can remember the actions that my sister did, I do not appropriate them. In other words, I only appropriate actions that I performed myself. Again, it is unlikely that Mackie considered this meaning, because it renders his argument inconsistent. Given his assumption that in order for action appropriation to provide persistence conditions for persons, $P_{2}$ has to appropriate all the experiences and actions that $P_{1}$ was co-conscious at $t_{1}$, Mackie seems committed to the view that $P_{1}$ appropriates the actions that he or she perceived others doing at that time-yet this is exactly what this reading rejects. Consequently, each reading undermines the force of Mackie's argument.

A further deficiency of Mackie's argument is that he fails to properly motivate the strong and questionable assumption that all past experiences and actions have to be appropriated in order for action appropriation to provide a suitable account of personal identity. This is a pressing question, because there are alternative, and at least equally plausible, accounts of the persistence conditions for persons. For example, one might argue insteadinspired by certain Neo-Lockean views - that a sufficient number of past experiences and actions have to be appropriated. ${ }^{16}$ Mackie may respond that such a proposal is a revision of Locke's view and does not properly accommodate Locke's aim to answer questions of moral accountability with his theory. At this stage, it is worth drawing attention to the fact that I am conscious of more

${ }^{16}$ For instance, according to Derek Parfit, '[f]or $\mathrm{X}$ and $\mathrm{Y}$ to be the same person, there must be over every day enough direct psychological connections' (Reasons and Persons (Oxford, 1984), 206). If Neo-Lockean theories succeed in offering an account of personal identity then it is unclear why Mackie claims that an account of personal identity in terms of action appropriation requires that all past experiences and actions are appropriated rather than a sufficient number of past experiences and actions. Note that this comparison with Neo-Lockean views is merely meant to challenge Mackie's assumption and is not intended to be an endorsement of Neo-Lockean interpretations of Locke. 
than morally significant experiences and actions, since many thoughts and actions are morally neutral in the sense that one neither deserves reward nor punishment for having done or doing them. This observation invites a distinction between morally significant experiences and actions and those that are not morally significant. Since Locke-as Mackie acknowledges-is particularly interested in questions of moral accountability throughout his discussion of personal identity, it is plausible that he may have given morally significant experiences and actions different weight than other experiences and actions. ${ }^{17}$ On this basis, we can now contrast Mackie's premise (3) with two alternative accounts of the persistence conditions for persons and distinguish the three following positions:

(PI $\mathbf{I}_{1}$ A person $P_{l}$ existing at $t_{l}$ is the same person as a person $P_{2}$ existing at $t_{2}$ if and only if $P_{2}$ is able to be conscious of all of the morally significant experiences and actions that $P_{1}$ was co-conscious.

(PI $)_{2}$ A person $P_{1}$ existing at $t_{1}$ is the same person as a person $P_{2}$ existing at $t_{2}$ if and only if $P_{2}$ is able to be conscious of all of the morally significant experiences and actions which $P_{1}$ was co-conscious and of a sufficient number of other experiences and actions that $P_{l}$ was co-conscious.

(PI $\mathbf{I}_{3}$ A person $P_{1}$ existing at $t_{1}$ is the same person as a person $P_{2}$ existing at $t_{2}$ if and only if $P_{2}$ is able to be conscious of all of the experiences and actions that $P_{1}$ was co-conscious.

In support of $\left(\mathrm{PI}_{1}\right)$ it can be argued that the restriction to morally significant thoughts and actions is in accordance with Locke's aim to address questions of accountability. Locke introduces the notion of a person in addition to the notions of a human organism, or 'man' to use Locke's term, and a substance in order to trace the continued existence of a subject of

${ }^{17}$ Since for Locke appropriation is a necessary condition for moral accountability, morally significant actions will be actions that a self is able to appropriate. However, it is an open question whether there are appropriated thoughts or actions that are not morally significant. I want to be neutral on this issue and for this reason I do not formulate the following positions in terms of appropriation. 
accountability over time. ${ }^{18}$ According to Locke, if we want to decide whether an individual now is the same person, or subject of accountability, as an individual that committed a crime, bodily continuity will neither be sufficient nor necessary. It is not sufficient, because an individual may have irretrievably forgotten a past crime and yet the body continues to exist (see II.xxvii.20). Locke's prince-cobbler example is meant to show that bodily continuity is not necessary (see II.xxvii.15). Similarly, Locke argues that sameness of substance is neither necessary nor sufficient for the continued existence of a person, or subject of accountability. Thus, Locke believes that it is important to introduce the term 'person' to properly address questions of accountability. Given that Locke's account of personal identity is intended to track accountability, it seems pointless to include morally neutral experiences and actions into the persistence conditions for persons.

However, one can defend $\left(\mathrm{PI}_{2}\right)$ against $\left(\mathrm{PI}_{1}\right)$ by arguing that including consciousness of some morally neutral experiences and actions will help a person to trace the morally significant actions within his or her past, because $\left(\mathrm{PI}_{1}\right)$ may be too thin for a person to realize how an action was connected with other past experiences. Locke argues in II.xxvii.22 that in the Great Day one's conscience will accuse or excuse oneself. This provides support for the view that an individual shall understand the justice of reward and punishment from a first personal perspective.

Let us turn to $\left(\mathrm{PI}_{3}\right)$ - the view that underlies Mackie's argument. Due to forgetfulness $\left(\mathrm{PI}_{3}\right)$ will be less often satisfied than $\left(\mathrm{PI}_{1}\right)$ and $\left(\mathrm{PI}_{2}\right)$. This calls into question the plausibility of $\left(\mathrm{PI}_{3}\right)$, because it is problematic to accept that one ceases to be the same person as a past self by forgetting morally insignificant experiences or actions of the past self. For example, it follows that one ceases to be the same person merely by forgetting morally insignificant experiences such as the colour of the shirt that one's mother was wearing a week ago. This result is

${ }^{18}$ For further discussion why it is plausible to regard Lockean persons as subjects of accountability see Boeker, 'The Moral Dimension of Locke's Account of Persons and Personal Identity'. 
particularly unmotivated if we take seriously Locke's aim to address questions of accountability.

Consequently, $\left(\mathrm{PI}_{1}\right)$ and $\left(\mathrm{PI}_{2}\right)$ are more plausible candidates than $\left(\mathrm{PI}_{3}\right)$. On this basis we can conclude that Mackie's premise (3), which assumes $\left(\mathrm{PI}_{3}\right)$ and does not acknowledge the possibility of $\left(\mathrm{PI}_{1}\right)$ or $\left(\mathrm{PI}_{2}\right)$, is not well supported. Since Mackie emphasizes that moral accountability is at the heart of Locke's theory, Mackie could welcome $\left(\mathrm{PI}_{1}\right)$ and $\left(\mathrm{PI}_{2}\right)$ as more sympathetic interpretations of Locke. There is no need to take a stance on whether $\left(\mathrm{PI}_{1}\right)$ or $\left(\mathrm{PI}_{2}\right)$ provides the better account of personal identity, as long as a person will be accountable for the same actions. ${ }^{19}$

To sum up, Mackie argues that Locke's theory is a theory of action appropriation, but he takes this to be an objection, because appropriation is not suitable to provide proper persistence conditions for persons. However, as I argued, Mackie's argument can be criticized on several grounds: First, it assumes without further argument that appropriation is meant to provide persistence conditions for persons. Second, Mackie either equates appropriation with consciousness or memory in general and so does not leave room for appropriation to play a distinctive role in Locke's theory, or appropriation will have to be understood in a sense that is inconsistent with Mackie's argument. Furthermore, I argued that his assumptions concerning the persistence conditions for persons are very demanding and lack motivation in light of alternative accounts that are more sympathetic to Locke's view.

We can conclude that Mackie's argument, due to its flaws, is not a reliable source to support an interpretation of Locke's account of appropriation, and, in particular, it does not provide adequate support for the appropriation interpretation. Next, let us turn to Winkler's interpretation to see whether his view is more promising.

${ }^{19}$ One may argue that all experiences and actions are morally significant and that, consequently, $\left(\mathrm{PI}_{1}\right)$ collapses into $\left(\mathrm{PI}_{3}\right)$. I do not have an argument to rule out this possibility in principle. However, my main point still holds, namely, that Mackie owes us a further justification for why he endorses the very demanding condition $\left(\mathrm{PI}_{3}\right)$. Note further that the options discussed here are not meant to be exhaustive. 


\section{§3. Winkler on Subjective Constitution and The Problem of Reconciling Appropriation and the Possibility of Divine Adjustments}

Winkler's main contribution, as we will see in a moment, consists in his claim that appropriation plays an important role with respect to a person's or self's subjective constitution. We will have to examine whether, according to him, appropriation is merely involved in the constitution of a person at a time, or whether it additionally provides alternative persistence conditions for persons - as is assumed by the so-called appropriation interpretation in the more recent literature. He ends the paper by acknowledging that appropriation, or the subjective constitution of a person, is hard to reconcile with the possibility of objective divine adjustments. Yaffe and Weinberg argue that the appropriation interpretation is to be rejected due to this problem and, hence, it is worth examining it closely. Let us turn to the details of Winkler's view.

According to Winkler, a self's or person's own constitution provides the basis of Locke's account of persons and personal identity:

I am proposing that Locke is interested in a sense of the word self according to which what the self includes depends on what it appropriates. I think we can all imagine finding a place for such a notion. "Perhaps soand-so did commit the crime, but if he is not aware of having done it, then there is a sense in which the action is not his own." ('Locke on Personal Identity', 205)

As $§ 26$ makes clear, the self has a certain authority over its constitution. It is important to realize that this authority is not consciously exerted. I do not wilfully disown one act and appropriate another, instead I accept what my consciousness reveals to me. ('Locke on Personal Identity', 206)

Winkler emphasizes the authoritative role that a self has over his or her own constitution. He also calls this the 'subjective 
constitution' of a self. ${ }^{20}$ By this he means that any criticism must be based on the self's own appropriations. ${ }^{21}$

As before, we can ask whether appropriation plays a distinctive role or whether it reduces to consciousness. According to Winkler, consciousness is clearly a necessary condition for appropriation, but does he also regard it to be sufficient? He does not engage with this question, yet it can be argued that I am aware of more actions than those that I appropriate. For example, I can be aware of my sister's actions by observing her, but I would not appropriate her actions as my own actions. Since Winkler argues that one must be aware of having committed a crime in order to appropriate it, I believe that he would be happy to acknowledge a difference between mere conscious awareness and action appropriation or, at least, he would be happy to regard appropriation as a special kind of conscious awareness. ${ }^{22}$ Hence consciousness is necessary for appropriation but appropriation cannot be equated with consciousness in general. This creates scope for appropriation to play a distinctive role in Locke's theory.

Winkler's claims so far establish that appropriation plays an important role with respect to a person's constitution at a time, but we have not yet encountered an argument for the further claim that appropriation provides alternative persistence conditions for persons. He does not explicitly distinguish these two questions and remains vague on the latter. Nevertheless, he maintains that 'the constitution of the self takes place over time' (207) and that the self over time cannot be constituted by consciousness alone due to the problem of transitivity that Berkeley and Reid raised for Locke's theory. ${ }^{23}$ In response to this

${ }^{20}$ Winkler, 'Locke on Personal Identity', 201, 204, 208, 209, 220, 222, 223, 225.

${ }^{21}$ See Winkler, 'Locke on Personal Identity’, 208.

${ }^{22}$ See Winkler, 'Locke on Personal Identity', 205.

23 See Winkler, 'Locke on Personal Identity', 206-8. See George Berkeley, Alciphron, or The Minute Philosopher, in The Works of George Berkeley Bishop of Cloyne, ed. A. A. Luce and T. E. Jessop (9 vols., London, 1950), iii, 299; Thomas Reid, Essays on the Intellectual Powers of Man, ed. Derek R. Brookes (Edinburgh, 2002), III.vi, 276. 
problem Winkler proposes that Locke could easily accept that personal identity over time is constituted by the ancestral of the co-consciousness or memory relation. For present purposes, I will not further engage with the question whether replacing the coconsciousness or memory relation with the ancestral of that relation provides a satisfying solution to the problem of transitivity, because it leads astray from the actual topic of this paper. $^{24}$ The more important question here is whether Winkler's view that personal identity is constituted by the ancestral of the co-consciousness or memory relation leaves room for appropriation to provide alternative persistence conditions for persons. He does not give any indication that he intends his interpretation of Locke's account of personal identity to provide an alternative account, but rather he presents it as a version of a psychological account of personal identity. Otherwise he would and should have made explicit that he intended to offer an alternative account. In the absence of such clarification, we have reason to conclude that, according to Winkler, appropriation is relevant for the constitution of a self at a time, but is not intended to replace psychological accounts of personal identity.

Having argued that appropriation or subjective constitution plays an important role in Locke's account of persons, Winkler ends his paper by raising a tension between the subjective constitution of a person and objective third-personal criticism and adjustments. ${ }^{25}$ It is important for Locke to leave room for the possibility of objective adjustments or criticisms, because he takes seriously the possibility of divine rectification at the Last Judgement (see II.xxvii.13, 15, 21-22, 26; IV.iii.6; IV.xvviii). ${ }^{26}$

${ }^{24}$ For further discussion see Nicholas Jolley, Locke: His Philosophical Thought (Oxford, 1999), 120-21; E. J. Lowe, Locke on Human Understanding (Abingdon, 1995), 112-14; Mackie, Problems from Locke, 178-83; Harold W. Noonan, Personal Identity, $2^{\text {nd }}$ edn. (Abingdon, 2003), 55-56; Strawson, Locke on Personal Identity, 5357, chs. 10-11; Matthew Stuart, Locke's Metaphysics (Oxford, 2013), ch. 8, especially $353-59,378-85$.

${ }^{25}$ See Winkler, 'Locke on Personal Identity', 209-11, 220-23.

${ }^{26}$ See also John Locke, Writings on Religion, ed. Victor Nuovo (Oxford, 2002), especially 'Resurrectio et quae sequuntur', 232-37. 
The doctrine of divine rectification says that God at the Great Day will reward and punish persons for their doings in this life, and, if necessary, correct human injustice. ${ }^{27}$ In order for God to justly reward or punish people at the Great Day an objective standard will be needed that guarantees, or enables God to make adequate adjustments such that, resurrected persons acknowledge all their past thoughts and actions and only their past thoughts and actions. ${ }^{28}$ However, is there room for such objective divine adjustments if the self is subjectively constituted?

Winkler argues that it is difficult to reconcile appropriation with the possibility of divine adjustment. He connects the difficulty to a dilemma that Flew raised many years ago for Locke's theory. ${ }^{29}$ Flew distinguishes phenomenal or seeming memory from genuine memory and argues that Locke's theory collapses on either understanding of memory: ${ }^{30}$ On the one hand,

27 See Weinberg, 'Author Meets Critics on Antonia LoLordo's "Locke's Moral Man": Shelley Weinberg'; 'The Metaphysical Fact', 389.

${ }^{28}$ See Winkler, 'Locke on Personal Identity', 220. Winkler's and Weinberg's views concerning the possibility of divine rectification are similar. LoLordo agrees that the theory must provide scope for divine rectification, but denies the need for divine adjustments, because, according to her, there will be no misappropriations. See LoLordo, 'Author Meets Critics on Antonia LoLordo's "Locke's Moral Man": LoLordo's Reply to Weinberg'; Locke's Moral Man, 70-74. LoLordo's arguments against misappropriations depend on a non-transitive interpretation of Locke's account of personal identity. Although such interpretations have been defended by Mackie, Problems from Locke, 178-83, Strawson, Locke on Personal Identity, 53-57, chs. 1011, and Stuart, Locke's Metaphysics, ch. 8, especially 353-59, 378-85, the debate is not settled. I prefer to be neutral on whether Locke's account of personal identity is transitive or not and hence I do not follow LoLordo in assuming that misappropriation is impossible; rather I believe that a theory that can incorporate misappropriations has broader scope.

${ }^{29}$ See Anthony Flew, 'Locke and the Problem of Personal Identity', Philosophy 26 (1951): 58 .

${ }^{30}$ I will follow Flew in presenting the dilemma in terms of memory. However, it is worth noting that Locke's notion of consciousness is not to be reduced to memory, because it includes consciousness of the present and extends into the future (see Margaret Atherton, 'Locke's Theory of Personal Identity', Midwest Studies in Philosophy 8 (1983): 273-93; Matthews, 'Descartes and Locke on the Concept of a Person', 28-30; Marya Schechtman, The Constitution of Selves (Ithaca, NY, 1996), 105-12, especially 107; Strawson, Locke on Personal Identity, ch. 9; Udo Thiel, Lockes Theorie der personalen Identität, 129-31, and his The Early Modern Subject (Oxford, 
if memory is understood in terms of phenomenal memory, then whatever I seem to remember was done by me. As a consequence Locke's theory would not leave room for error. However, Locke mentions in II.xxvii.13 the possibility of 'fatal Error' and this conflicts with the phenomenal memory reading. On the other hand, if memory is understood in terms of genuine memory, Flew argues that Locke has to give up his view that personal identity consists in sameness of consciousness, admitting, according to Flew, that 'same person' has to be defined at least partially in terms of 'same thinking substance' ('Locke and the Problem of Personal Identity', 58).

Winkler engages with the problem raised by Flew, and acknowledges:

The problem is that if we respond by saying that any thought or action appropriated by my present self is in fact mine, we lose (as Flew in effect insists) the possibility of divine criticism ('Locke on Personal Identity', 221)

At the very least, Flew's objection shows that the dominant themes in Chapter 27-the subjective constitution of the self, and the possibility of objective criticism and adjustment — cannot easily be combined ('Locke on Personal Identity', 222)

It is right that if memory can be reduced to phenomenal memory, then the view will not leave room for divine criticism. However, the problem with Winkler's analysis of the tension is that he follows Flew in understanding Locke's account of memory in terms of phenomenal memory. Yet there is no good textual support for understanding Locke's account of memory in this way. Memory, according to Locke, requires previous awareness of the thought or action remembered (see I.iv.20, II.x. 2,7$):^{31}$

2011), 109, 122-26). However, consciousness of past thoughts and actions involves memory (see I.iv.20, II.x).

31 See Don Garrett, 'Locke on Personal Identity, Consciousness, and "Fatal Errors", Philosophical Topics 31 (2003): 100-2. 
this laying up of our Ideas in the Repository of the Memory, signifies no more but this, that the Mind has a Power, in many cases, to revive Perceptions, which it has once had, with this additional Perception annexed to them, that it has had them before. (II.x.2)

The previous awareness condition of memory makes it possible to distinguish imaginary memories from genuine memories, at least from a divine perspective, because in the case of imaginary memories there has never been a previous perception of the thing or event that one now seems to remember.

Although Winkler presents the problem as a tension between appropriation and the possibility of divine rectification, closer inspection shows that it concerns a tension between phenomenal memory and the possibility of divine rectification. Since Locke does not understand memory in terms of phenomenal memory, the problem can be avoided.

Given the previous analysis, namely, that appropriation is relevant for the constitution of a person at a time but is not intended to provide alternative persistence conditions for persons, this result is not surprising. The objective standard that is needed for divine adjustments has to be built into the relation that constitutes personal identity over time. Since appropriation on Winkler's view does not provide alternative persistence conditions, there is no specific problem concerning appropriation. If there is a tension, then it has broader scope and concerns psychological accounts of personal identity more generally.

\section{\$4. Revisiting the So-Called Appropriation Interpretation}

In the more recent literature the so-called appropriation interpretation is often ascribed to Winkler. However, in light of the previous critical discussion of Mackie's and Winkler's interpretations, we have to revisit whether the appropriation interpretation is subject to the same problems and whether there is support for such a view.

To begin, let me put aside Yaffe's and Weinberg's criticism of the appropriation interpretation. Both reject it due to the apparent problem that appropriation does not leave room for objective 
criticism. ${ }^{32}$ However, as the discussion above has shown, this problem is merely apparent and arises because Winkler follows Flew in interpreting memory in terms of phenomenal memory. Since this reading is not supported by Locke's text, Yaffe's and Weinberg's criticisms are undermined too.

It remains to consider whether appropriation can provide alternative persistence conditions, as Yaffe, Weinberg, and LoLordo assume when they introduce the appropriation as an alternative to the memory interpretation. They do not offer a detailed argument, but rather they ascribe the view to Winkler, and sometimes more remotely to Mackie. However, as we have seen, neither Mackie nor Winkler offer arguments in support of the claim that appropriation is meant to provide alternative persistence conditions. Consequently, the view is unsupported in the absence of another argument.

I will return to these issues in the final section. However, first it is important to re-examine Locke's texts closely. This is the task to which I turn now.

\section{§5. The Role of Appropriation in Locke's Texts}

In light of the problems that arise for Mackie's and Winkler's discussion of appropriation, and the subsequent lack of support for the so-called 'appropriation interpretation', it is fair to say that a satisfying understanding of the role that appropriation plays in Locke's account of persons and personal identity is missing. This makes it worth returning to Locke's texts and to re-examine his own understanding of appropriation. The problems identified in the previous considerations make it interesting to draw particular attention to the following questions: First, is appropriation relevant for the constitution of a person at a time? Second, is appropriation meant to provide a new self-standing account of the persistence conditions for persons? While Winkler puts emphasis on the former and is vague with regard to the latter, the problem with Mackie's view is that he believes the latter.

32 See Weinberg, 'Author Meets Critics on Antonia LoLordo's "Locke's Moral Man": Shelley Weinberg'; 'The Metaphysical Fact', 389-90; 'Locke on Personal Identity', 401-2; Yaffe, 'Locke on Ideas of Identity and Diversity', 223. 
Since Locke mentions appropriation in his chapter 'Of Identity and Diversity' explicitly only in II.xxvii.16 and 26, it will be helpful to consider whether his other writings help to provide a fuller understanding of his account of appropriation and its role in his discussion of persons and personal identity. Besides the Essay, the second of Locke's Two Treatises of Government is an important source, because appropriation is relevant in the chapter 'Of Property' (Two Treatises, II.v). ${ }^{33}$ I will therefore briefly turn to Locke's Two Treatises to consider whether Locke's understanding of appropriation there helps to illuminate his discussion in Essay II.xxvii.

There are interesting terminological parallels between Locke's discussion of persons and personal identity in Essay II.xxvii and his discussion of property in Two Treatises II.v, though we have, of course, to be cautious not to stretch the parallels too far, because the Essay is a philosophical work in which Locke aims for terminological precision, while in Two Treatises he follows ordinary language use and does not distinguish the terms 'person' and 'man'. ${ }^{34}$ While in the Essay Locke speaks of the appropriation of actions by consciousness, in Two Treatises he discusses appropriation of external objects by labour. He argues in Two Treatises that by mixing one's labour with common goods such as fruits, animals or land they become one's property or one

33 References to Locke, Two Treatises are to John Locke, Two Treatises of Government, ed. Peter Laslett (Cambridge, 1988). See Ayers, Locke, ii, 266-68; Thomas Mautner, 'Locke's Own', The Locke Newsletter 22 (1991): 73-80; Thiel, Lockes Theorie der personalen Identität, 116-17, especially note 28; John W. Yolton, Locke: An Introduction (Oxford, 1985); Naomi Zack, 'Locke's Identity Meaning of Ownership', The Locke Newsletter 23 (1992): 105-13, for discussion of the role of appropriation in II.xxvii in relation to Locke's Second Treatise and natural law theory. Further literature on appropriation and ownership which focuses on the Second Treatise includes Stephen Buckle, Natural Law and the Theory of Property: Grotius to Hume (Oxford, 1991), 149-90; J. P. Day, 'Self-Ownership', The Locke Newsletter 20 (1989): 77-85; Karl Olivecrona, 'Appropriation in the State of Nature: Locke on the Origin of Property', Journal of the History of Ideas 35 (1974): 211-30, 'Locke's Theory of Appropriation', The Philosophical Quarterly 24 (1974): 220-34; James Tully, A Discourse on Property: Locke and his Adversaries (Cambridge, 1980).

${ }^{34}$ For further discussion see Ayers, Locke, ii, 266-68; Timothy Stanton, 'Christian Foundations; or Some Loose Stones? Toleration and the Philosophy of Locke's Politics'; Thiel, Lockes Theorie der Personalen Identität, 116-17, especially note 28. 
makes them one's own (see Two Treatises, II.v.26-39). Hence, in this context 'to appropriate something' means 'to make it one's own'. The following passages further illustrate this point:

God, who has given the World to Men in common, hath also given them reason to make use of it to the best advantage of Life, and convenience... yet being given for the use of Men, there must of necessity be a means to appropriate them [i.e. the fruits and beasts] some way or other before they can be of any use, or at all beneficial to any particular Man. The Fruit, or Venison, which nourishes the wild Indian, who knows no Inclosure, and is still a Tenant in common, must be his, i.e. a part of him, that another can no longer have any right to it, before it can do him any good for the support of his Life.

Though the Earth, and all inferior Creatures be common to all Men, yet every Man has a Property in his own Person. The Labour of his Body, and the Work of his Hands, we may say, are properly his. Whatsoever then he removes out of the State that Nature hath provided, and left in it, he hath mixed his Labour with, and joyned to it something that is his own, and thereby makes it his Property. It being by him removed from the common state Nature placed it in, it hath by his labour something annexed to it, that excludes the common right of other Men. For this Labour being the unquestionable property of the Labourer, no Man but he can have a right to what that is once joyned to, at least where there is enough, and as good left in common for others. (Two Treatises, II.v.26-27)

How can we understand Locke's claim that common goods become part of oneself by appropriation? Locke stands in the natural law tradition, and in natural law theory it was common to describe what belongs to a person with the term suum-one's own. ${ }^{35}$ Grotius, for example, argues that “[b]y nature, a man's life is his own, not indeed to destroy, but to safeguard; also his own are his body, limbs, reputation, honour, and the acts of his will." (On the Law of War and Peace, 2.17.2.1). ${ }^{36}$ The suum can be

35 See Buckle, Natural Law and the Theory of Property; Olivecrona, 'Locke's Theory of Appropriation'; Zack, 'Locke's Identity Meaning of Ownership'.

${ }^{36}$ References to On the Law of War and Peace are to Hugo Grotius, On the Law of War and Peace, ed. Stephen C. Neff (Cambridge, 2012). Similarly as Grotius, Samuel Pufendorf lists 'our Life, our Bodies, our Members, our Chastity, our Reputation, and our Liberty' as 'Things which we receive from the immediate Hand of Nature' (Of the Law of Nature and Nations, ed. Jean Barbeyrac (London, 1729), 3.1.1). 
regarded as the sphere of personality and it is often thought to extend to external objects. By making something one's own one gains a special right to use the things one appropriated and one is entitled to expect reparation if others damage the things belonging to the suum. ${ }^{37}$ The term suum was translated by 'propriety' and 'property' into seventeenth-century English. ${ }^{38}$ In Two Treatises II.v.27, Locke argues that property includes not only external objects, but also that everyone 'has a Property in his own Person' and that labour is the property of the labourer. Thus Locke's notion of property has its origin in the notion of the suum. ${ }^{39}$ By investing labour we appropriate something, or make it our own.

It is now time to turn to the relevant passages in Locke's Essay. Within his discussion of persons and personal identity Locke mentions appropriation only in II.xxvii.16 and 26 explicitly:

For as to this point of being the same self, it matters not whether this present self be made up of the same or other Substances, I being as much concern'd, and as justly accountable for any Action was done a thousand Years since, appropriated to me now by this self-consciousness, as I am, for what I did the last moment. (II.xxvii.16)

Person...is a Forensick Term appropriating Actions and their Merit; and so belongs to intelligent Agents capable of a Law, and Happiness and Misery. This personality extends it self beyond present Existence to what is past, only by consciousness, whereby it becomes concerned and accountable, owns and imputes to it self past Actions, just upon the same ground, and for the same reason, that it does the present. All which is founded in a concern for Happiness the unavoidable concomitant of consciousness, that which is conscious of Pleasure and Pain, desiring, that

${ }^{37}$ See Pufendorf, Of the Law of Nature and Nations, 4.4.

38 The terms 'propriety' and 'property' were often used interchangeably in the seventeenth century. Locke tended to use 'propriety' and changed it into 'property' in later versions of his work. See Buckle, Natural Law and the Theory of Property, 17273.

${ }^{39}$ For further discussion see Buckle, Natural Law and the Theory of Property, 16973; Olivecrona, 'Locke's Theory of Appropriation'. 
that self, that is conscious, should be happy. And therefore whatever past Actions it cannot reconcile or appropriate to that present self by consciousness, it can be no more concerned in, than if they had never been done (II.xxvii.26).

In these passages Locke speaks explicitly of the appropriation of past actions by consciousness, but his claim in II.xxvii.26 that a person 'owns and imputes to it self past Actions, just upon the same ground, and for the same reason, that it does the present' suggests that appropriation extends also to present actions.

By appropriating something one owns it. ${ }^{40}$ However, does 'to appropriate something' mean 'to make something one's own' in the Essay as well as in Two Treatises? ${ }^{41}$ We find support for this reading in II.xxvii.24 where Locke states that I make thoughts and actions my own by my consciousness. Furthermore, the proposal that Locke continues to use appropriation in the sense of 'making one's own' fits squarely with Locke's aim to offer an account of persons and personal identity that addresses questions of moral accountability. In order to hold a person accountable for an action, there has to be a way to decide whether the action is his or her own, because a person is not held accountable for the actions of others, at least if he or she is ignorant of them. This means just accountability presupposes a way of distinguishing the actions of one person from the actions of all other persons. If appropriation is understood as a means of making something

${ }^{40}$ In addition to II.xxvii.26, this reading is suggested by II.xxvii.17: 'That with which the consciousness of this present thinking thing can join it self, makes the same Person, and is one self with it, and with nothing else; and so attributes to it self, and owns all the Actions of that thing, as its own, as far as that consciousness reaches, and no farther; as every one who reflects will perceive.' See also II.xxvii.14, 18, 24, 26.

${ }^{41}$ This reading has been questioned by Mautner, 'Locke's Own', who argues that there are two senses of own: One is the familiar possessive sense, and the other is an older usage, according to which 'to own' means 'to state, declare, admit, confess, acknowledge it' (74). According to Mautner, Locke's notion of own in the Essay is to be understood in the declarative sense. For a critical response see Zack, 'Locke's Identity Meaning of Ownership'. I believe that it is difficult to understand Locke's use of 'own' in II.xxvii in a purely declarative sense. For example, the expression 'as its own', which is part of the statement 'and owns all the Actions of that thing, as its own, as far as that consciousness reaches' (II.xxvii.17), can hardly be interpreted in the purely declarative sense, but rather introduces a reflexive, if not possessive, element. 
one's own, then appropriation distinguishes my actions from the actions of others and plays an interesting role in Locke's theory.

As already mentioned it is plausible to suppose that Locke's account of appropriation in the Essay involves action appropriation both at a time when an action is initially performed and at a later time when we acknowledge a previously performed action as our own. I will call the former 'appropriation of present actions' and the latter 'appropriation of past actions'. It is worth asking separately how the appropriation of present and past actions is to be understood.

To begin with the appropriation of present actions, at the present moment I can be conscious of many actions. However, this awareness by itself does not make an action my own action, because I can also observe the actions of others. The difference between my actions and the actions of others is that I perform my actions and that I am aware of performing them. Since I can also perceive other people performing actions, this difference cannot be exclusively explained with reference to the content of the perception, namely my representation of the performance of the action, but rather when I perceive an action as my own I have an intimate experience of doing the action, namely, an experience of the physical and/or cognitive labour that I invest. It is worth noting that purely physical movements of one's body such as those of a sleepwalker will not be sufficient for action appropriation, because in such cases one lacks awareness of performing the action. Since all present actions that one appropriates involve awareness of one's performance of the action, action appropriation will be accompanied by a distinctive inner experience of the physical and/or cognitive labour.

To further support why I believe that the appropriation of present actions is accompanied by a distinctive inner experience of the labour that one invests, I want to draw attention to Locke's remarks about sensitive knowledge:

But yet here, I think, we are provided with an Evidence, that puts us past doubting: For I ask any one, Whether he be not invincibly conscious to himself of a different Perception, when he looks on the Sun by day, and thinks of it by night; when he actually tastes Wormwood, or smells a Rose, 
or only thinks on that Savour, or Odour? We as plainly find the difference there is between an Idea revived in our Minds by our own Memory, and actually coming into our Minds by our Senses, as we do between any two distinct Ideas (IV.ii.14).

For he that sees a Candle burning, and hath experimented the force of its Flame, by putting his Finger in it, will little doubt, that this is something existing without him, which does him harm, and puts him to great pain: which is assurance enough, when no Man requires greater certainty to govern his Actions by, than what is as certain as his Actions themselves (IV.xi.8).

These passages support that, according to Locke, performing an action, such as eating pineapple, running a mile, or moving one's arm, involves a distinctive experience which is not present when one merely thinks about an action, remembers an action, dreams about an action, or perceives the actions of others. This suggests that the initial performance of an action is accompanied by a distinctive inner experience, which provides a means for distinguishing my present actions from the actions of others, because when I am merely aware of actions of others I do not invest physical or cognitive labour and they lack the distinctive inner experience that accompanies my own actions.

To sum up, neither the performance of an action nor the awareness of action performance is by itself sufficient for action appropriation. In order for appropriation of present actions to take place, an individual needs to perform an action and be aware of performing the action and this awareness will be accompanied by an intimate experience that is distinctive of the physical and/or cognitive labour that one invests. ${ }^{42}$ This means that appropriation

${ }^{42}$ Locke's statement in II.xxvii.16 that I am accountable 'for what I did the last moment' supports the proposal the appropriation of present actions involves the performance of the action, because Locke does not merely claim that I am accountable for what I was conscious of the last moment. Similarly, he claims in II.xxvii.26 that a person that committed actions shall deserve punishment. The view defended here differs from Ayers's claim that '[o]ur actions themselves... are 'appropriated' to us by an entirely natural and given principle of unity, namely consciousness, rather than by some acquisitive act of acknowledgement or 'owning' on our part.' (Locke, ii, 268). I believe that my interpretation can be defended against Ayers's, because he does not carefully distinguish between the appropriation of present and past actions and generalizes the claim that past actions are appropriated by consciousness. 
of present actions is not explained exclusively in terms of consciousness, because it additionally involves the performance of the action. Moreover, the conscious awareness that accompanies the performance of the action is intrinsically different from other conscious experiences that are not appropriated.

Let us turn to the appropriation of past actions. According to Locke, we appropriate past actions by consciousness (see II.xxvii.16, 26). The question to consider is whether and how appropriation of past actions by consciousness is sufficient to distinguish my past actions from the past actions of others. To answer this question we have to look deeper into Locke's account of consciousness and memory. According to Locke, to be conscious of a past action is to remember the past action. As stated above, for Locke memory of a past action requires previous awareness of the action (see I.iv.20, II.x.2, 7). ${ }^{43}$ This means that when I remember a past action I remember having done or having perceived a past action rather than merely remembering that a past action took place. ${ }^{44}$ Given Locke's understanding of memory and the proposed account of the appropriation of present actions, I want to suggest that a past action is appropriated on the basis of remembering the previous performance of the action, which includes remembering the distinctive inner experience that accompanied the performance of the action. If this is correct, then it is possible to distinguish my past actions from the past actions of others: My past actions are the actions that I appropriated previously by performing them and experiencing the performance of them. It follows that the appropriation of past actions is to be understood in terms of the initial appropriation and memory. This means that the appropriation of past actions is not another type of action appropriation, but rather it can be explained in terms of remembrance of the initial act of appropriation, which took place at the time when the action was performed.

${ }^{43}$ See also Garrett, 'Locke on Personal Identity, Consciousness, and "Fatal Errors"'.

${ }^{44}$ Locke's account of memory can be classified as episodic memory. For further details concerning different varieties of memory see Rebecca Copenhaver, 'Thomas Reid's Theory of Memory', History of Philosophy Quarterly 23 (2006): 175-79. 
As a consequence of this proposal one has to accept that subjects do not have a choice whether or not to appropriate a past action, but rather, if their memory presents a past action as performed by them, they have to acknowledge the action as their action. $^{45}$ As soon as one's memory revives the initial act of appropriation and makes one aware again or the physical and/or cognitive labour that one invested, one acknowledges that one did the action and thereby appropriates it. However, it is a further question whether by appropriating a past action one acknowledges that one deserves reward or punishment for this action.

For instance, let us assume someone stole figs regularly from a fig tree in the neighbourhood. If we assume further that the person confessed the deed a few years later and properly repaid his or her neighbours for the damage, then this is a case where the person still acknowledges that he or she stole the figs and appropriates the action as his or her own, but does not any longer regard him- or herself as blameworthy. Locke might have anticipated such examples in II.xxvii.26 where he not only speaks of the appropriation of actions, but also of the appropriation of merit for them. This means that although when my memory presents a past action as done by me I cannot deny that I did the action, I may, nevertheless, have a choice as to whether I accept merit for the action. Unfortunately, Locke says very little concerning the appropriation of merit for actions and whether or not the appropriation of actions has to be considered separately from the appropriation of merit for actions will ultimately depend on the particular understanding of merit or reward and punishment.

So far I proposed an interpretation of the appropriation of present and past actions. Although Locke speaks explicitly only of the appropriation of actions (see II.xxvii.16, 26), it is worth considering whether and how this interpretation extends to the

45 Winkler makes a similar remark: 'I do not wilfully disown one act and appropriate another; instead I accept what my consciousness reveals to me' ('Locke on Personal Identity', 206). 
appropriation of thoughts. ${ }^{46}$ Any reader who is convinced that Locke's account of appropriation is restricted to action appropriation can skip this part, because it is an additional component which supplements the account that I have given of action appropriation, but the account of action appropriation does not require it. According to my proposed interpretation, appropriation is a prerequisite for accountability and since some of our thoughts are morally significant it is plausible that one will not only be accountable and rewarded or punished for actions, but also for certain thoughts. In these cases it will be important to have a means of distinguishing my thoughts from the thoughts of others.

Let me begin with an example. The demonstration of a significant proposition can be a thought that deserves reward. Demonstrating a proposition will involve several individual steps and in each step of the proof one will invest cognitive labour and be aware of the cognitive labour one invests. Thus it can be said that by investing cognitive labour I make the demonstration my own. This suggests that the appropriation of a present demonstration can be understood by means of the cognitive effort one invests and one's awareness of that effort. In analogy to the appropriation of actions, it is plausible that a demonstration will be appropriated at a later time by remembering the previous act of appropriation. $^{47}$

To turn to another example, let us consider the invention of new things. According to Locke, ideas of modes are created in the mind. In contrast to ideas of substances, which are meant to represent real things in the world and capture the way the world is

${ }^{46}$ Locke claims in various passages that a person is conscious of thoughts and actions (see II.xxvii.9-10, 14-15, 19, 21, 24). Here and in the following I follow Locke and use 'thought' in a broad sense, interchangeably with Locke's equally broad term 'perception'.

${ }^{47}$ In IV.i.9 Locke observes that our memory of demonstrations often does not retain all the individual steps of a demonstration, but rather the memory merely retains a conviction of the proof. On this basis, in order to appropriate a past demonstration it may be sufficient that one is still aware that one demonstrated a proposition by one's own cognitive efforts even if one does not recall all the individual steps of the demonstration. 
independent of us, it is up to the creative mind to combine any ideas into the idea of a complex mode (see II.xxx, III.v, III.vi.46). Ideas of substances can be said to have a world-mind direction of fit, while ideas of modes have the opposite direction of fit. 'We do not pick out something in the world and then design a mode idea to correspond to it. Rather, we design a mode idea to serve certain purposes and then use it to refer to anything out in the world that happens to answer to it' ${ }^{48}$ Some ideas of modes exist in the mind, before any object corresponding to them exists in reality. Printing is an example of such a mode, because the idea of printing had to be formed in the mind of the inventor before any printing machines were built (see II.xxii.9). People who invent new things invest cognitive labour when they combine several simple ideas into a new complex idea and as part of this process they consider mental images of the things they aim to invent. Inventions of new things are further examples that make it plausible to say that certain thoughts are appropriated by investing cognitive labour.

The examples of thoughts considered so far both involve activity of the person who has them. In such cases it is plausible that appropriation of present thoughts takes place by investing cognitive labour. However, not all thoughts are active. Many are passive. For example, I perceive many things passively. This raises the question whether and how passive thoughts are candidates for appropriation. Passive thoughts provide information and access to information, or the lack thereof, can be morally significant. For example, if I perceive that a child is in danger, then I will receive morally significant information. The content that the child is in danger is not sufficient to make the perception my own, because it can in principle be shared by other people. The appropriation of passive perceptions such as this can be explained in one of the following two ways: First, it can be

48 Antonia LoLordo, 'Three Problems in Locke's Ontology of Substance and Mode', in Contemporary Perspectives on Early Modern Philosophy: Nature and Norms in Thought, ed. Martin Lenz and Anik Waldow (Dordrecht, 2013), 53. For a detailed discussion of Locke's distinction between modes and substances see also LoLordo, Locke's Moral Man, 74-82. 
suggested that the passive perception provides input that I then actively process, for instance, by actively reflecting on the situation and identifying ways to help. My active processing involves cognitive labour and as in the examples above appropriation can be said to consist in the cognitive labour that one invests.

Alternatively, one could draw attention to the inherent reflexivity of every perception. Locke argues in II.xxvii.9 that internal to the perception there is the perception that one has the perception. $^{49}$ This internal reflexive element is a distinctive inner experience that makes the perception my perception. The suggestion is that perceptions are appropriated by having them, which builds on Locke's claim that perceiving involves perceiving that one perceives (see II.xxvii.9). If I remember at a later time the previous perception, I will not merely remember that the child was in danger, but rather I will also remember my perceiving that the child was in danger. Thus, I will appropriate a past perception by remembering the previous appropriation of the perception.

This second model of appropriation is not restricted to passive thoughts. It can be extended to all thoughts. The view would be that all present thoughts are appropriated by having them and all past thoughts are appropriated by remembering the previous act of appropriation. While I believe that Locke's text leaves room for this interpretation, I want to offer a reason in favour of the first proposal.

The first model offers an account of appropriation of thoughts that is analogous to Locke's account of appropriation in Two Treatises. The view has the advantage that it can, in analogy to the account in Two Treatises, provide a basis for gaining particular rights with regard to appropriated thoughts, for instance, intellectual property rights. The cognitive labour that one invested can be seen as the basis for special rights with regard to the thoughts and thereby serve as a basis for reward or

49 For further discussion see Thiel, The Early Modern Subject, 114-16; Shelley Weinberg, 'The Coherence of Consciousness in Locke's Essay', History of Philosophy Quarterly 25 (2008): 26. 
punishment. If we adopted the second proposal, appropriation would not be a prerequisite for accountability and reward and punishment in any meaningful way. On the contrary, if active cognitive labour that a person invested is taken into consideration and if appropriation of thoughts is explained in terms of the cognitive labour that one invests, then we have a means to single out thoughts that are likely to have greater significance than others and be worthy of reward and punishment. Thereby the first model is suitable to offer an account of appropriation that is a prerequisite for accountability and reward and punishment, while the second is not.

My proposed interpretation of Locke's account of appropriation in the Essay is analogous to Locke's account of appropriation in Two Treatises. I believe that this is a strong feature of the interpretation and makes room for appropriation to play a distinctive role in Locke's theory, because in the Essay appropriation distinguishes my thoughts and actions from the thoughts and actions of others and this is a prerequisite for moral accountability.

\section{\$6. Appropriation and Persistence Conditions for Persons}

If we accept the interpretation of appropriation that I have given, then it follows that appropriation is relevant for the constitution of a person at a time. That means at a time when a person initially appropriates a thought or action that thought or action becomes a constitutive part of the person he or she is. Since the appropriation of past thoughts or actions is to be explained in terms of the initial appropriation and memory, no new additional act of appropriation takes place at that later time or during the intermittent period. Of course, Locke accepts that we appropriate past thoughts and actions, but the important point is that appropriation of past thoughts or actions can be traced back to the initial act of appropriation at the time when the action was performed or the thought was initially had and for this reason it is best understood as the revival of a previous appropriation, rather than a new appropriation. This is an important result, because it undermines the view that Locke's account of the persistence 
conditions is to be understood solely in terms of appropriation. The relations that explain why the earlier person is identical with the later person will be consciousness or memory relations, rather than self-standing relations of appropriation.

Since this point is crucial for distancing my interpretation from the so-called appropriation interpretation, let us look at the issues more closely. We can advance the debate by acknowledging the following distinctions: Persistence conditions are commonly expressed in terms of relations and we can distinguish the relation proper from the relata that stand in said relation. Psychological accounts of personal identity, including the memory interpretation, maintain that the relevant relations are psychological such as memory relations and that the relata are any thoughts, experiences, or actions one is or can be aware of. In principle, if appropriation provides the persistence conditions for persons, it can constitute or be part of the relation and/or the relata.

The discussion above has shown that the proposal that appropriation is supposed to provide alternative self-standing relations over time lacks support. Locke emphasizes that personal identity consists in sameness of consciousness. This itself is a strong reason to accept that the relevant relations are consciousness relations rather than relations of appropriation. ${ }^{50}$ Although Mackie presents Locke's theory as a theory of action appropriation he falls back to explaining the view in terms of psychological relations. Similarly Winkler argues that personal identity consists in co-consciousness or memory relations.

However, the second option is more promising, that is the view that appropriation helps to identify the relevant relata. While traditional psychological accounts of personal identity include any thoughts, experiences, or actions one is, or can be, aware of as potential relata, it can be argued that those thoughts, experiences, and actions that one acknowledges as one's own, or appropriates, should be given special weight. For instance, the relevant relata could be restricted to appropriated thoughts and

50 There is wide interpretive scope to spell out what exactly Locke means by sameness of consciousness. 
actions. On this view, the relevant relata are a subset of those that traditional psychological interpretations take into consideration. Alternatively, appropriated thoughts and actions could be given more weight so that one's identity as a person does not cease when one continues to be aware of formerly appropriated thoughts and actions, but has irretrievably forgotten other thoughts and actions that one observed and never appropriated. This view differs from traditional psychological accounts, because it introduces a qualitative component in addition to the quantitative counting of the number of existing of psychological connections.

The advantage of these proposals is that they focus on candidates for morally significant thoughts and actions ${ }^{51}$ and take seriously Locke's claim that 'person' is a forensic term (see II.xxvii.26), because, according to Locke, it is important that one acknowledges an action as one's own in order to be held accountable for it (see II.xxvii.22, 26). ${ }^{52}$ In this sense it can be said that appropriation is integrated into the persistence conditions for persons, but it is important to realize that it is built into the relata rather than the relations.

LoLordo is one of the few interpreters who endorses an appropriation interpretation, and it is worth commenting on how my proposal differs from her view. I believe that a main advantage of my proposal is that it achieves a new level of specificity that is lacking in LoLordo's interpretation. According to her, 'to extend your consciousness backward to an action is simply to appropriate it as your own or to impute it to yourself'. 53 This formulation is vague and can in principle be reconciled with either reading. However, had LoLordo intended to argue for the

51 I use the expression 'candidates for morally significant thoughts and actions', because all morally significant thoughts and actions will be among the appropriated thoughts and actions, but not all appropriated thoughts and actions need to be morally significant.

${ }^{52}$ Yaffe acknowledges that the appropriation interpretation can better accommodate Locke's claim that 'person' is a forensic term than the memory interpretation. See Yaffe, 'Locke on Ideas of Identity and Diversity', 222-23.

${ }^{53}$ LoLordo, Locke's Moral Man, 70. 
view that the proper place for appropriation is in the relata, then her initial characterization of the view should be refined to make this explicit.

One further point of difference is worth noting. LoLordo systematically rules out that there is misappropriation. If we adopt my distinctions, I prefer to rephrase the issue as the question of whether misrepresentations of one's past thoughts or actions are possible. On my interpretation this depends on the relations that connect the originally appropriated action with one's current revival of the original action appropriation. Since my account of appropriation is consistent with different views regarding the relations that constitute the persistence conditionsfor example, the relevant relations could be memory relations, psychological relations, causal relations, or a metaphysical fact of consciousness - the possibility of misrepresentation should not be systematically excluded, but rather it will depend on one's account of the relevant relations. The important point for present purposes is that the question whether Locke's theory leaves room for misrepresentation is independent from Locke's account of appropriation. Consequently, there is no reason to dismiss the importance of appropriation in Locke's theory due to the possibility of misrepresentation. ${ }^{54}$

The discussion so far has shown that the so-called appropriation interpretation lacks support, or, at least, it is vague. In contrast to this, the view that appropriation is to be located within the relata is more precise and has the further advantage that it does not regard appropriation as a rival to the different interpretations of Locke's persistence conditions for persons such as memory interpretations, psychological interpretations, or Weinberg's metaphysical fact account of consciousness. ${ }^{55}$ While,

54 It follows that the dispute between LoLordo and Weinberg concerning the possibility of misappropriation does not directly concern appropriation. See LoLordo, Locke's Moral Man, 72-74. Weinberg responds to these passages in 'Author Meets Critics on Antonia LoLordo's "Locke's Moral Man": Shelley Weinberg'. See also LoLordo's response in 'Author Meets Critics on Antonia LoLordo's “Locke's Moral Man”: LoLordo's Reply to Weinberg'.

${ }^{55}$ Weinberg argues in her work that Locke's account of personal identity involves an objective metaphysical fact of consciousness. According to her, God needs to be able 
for example, memory interpretations (or psychological interpretations more generally) and Weinberg's metaphysical fact interpretation are commonly presented as exclusive interpretations, appropriation, understood as proposed above, can be reconciled with either view. Regarding the former view, it can be said that memory relations connect appropriated thoughts actions at different times. Regarding the latter, a metaphysical fact of consciousness can be said to connect appropriated thoughts and actions. This is a promising result, because my interpretation provides a distinctive place for appropriation in Locke's theory and offers an explanation of why others who rejected or neglected appropriation were mistaken to do so. ${ }^{56}$

University College Dublin

to look at an objective fact when he rectifies failures of human justice at the Great Day. She maintains that the advantage of her interpretation is that it takes Locke's religious commitments seriously and that it is not subject to the problems that arise for memory interpretations. See Weinberg, "Locke on Personal Identity," "The Metaphysical Fact."

${ }^{56}$ I am grateful to Martha Brandt Bolton, Michael Della Rocca, James Harris, Antonia LoLordo, Kathryn Tabb, Shelley Weinberg, Kenneth Winkler, Joshua Wood and my anonymous referees of this and other journals for helpful comments on earlier version of this paper. I presented this work at the South Central Seminar in Early Modern Philosophy at Texas A\&M University in November 2011 and would like to thank my audience for helpful feedback.

\section{REFERENCES}

Allen, Keith. 'Cudworth on Mind, Body, and Plastic Nature', Philosophy Compass 8 (2013): 337-47.

Atherton, Margaret. 'Locke's Theory of Personal Identity', Midwest Studies in Philosophy 8 (1983): 273-93.

Ayers, Michael, Locke: Epistemology and Ontology. 2 vols. London: Routledge, 1991.

Behan, David P. 'Locke on Persons and Personal Identity', Canadian Journal of Philosophy 9 (1979): 53-75.

Berkeley, George. Alciphron, or The Minute Philosopher. In A. A. Luce and T. E. Jessop (Eds.), The Works of George Berkeley Bishop of Cloyne, vol. 3. London: Thomas Nelson and Sons, 1950.

Boeker, Ruth. 'The Moral Dimension in Locke's Account of Persons and 
Personal Identity', History of Philosophy Quarterly 31 (2014): 229-47.

Buckle, Stephen. Natural Law and the Theory of Property: Grotius to Hume. Oxford: Clarendon Press, 1991.

Copenhaver, Rebecca. 'Thomas Reid's Theory of Memory', History of Philosophy Quarterly 23 (2006): 171-89.

Day, J. P. 'Self-Ownership', The Locke Newsletter 20 (1989): 77-85.

Flew, Anthony. 'Locke and the Problem of Personal Identity', Philosophy 26 (1951): 53-68.

Garrett, Don. 'Locke on Personal Identity, Consciousness, and "Fatal Errors", Philosophical Topics 31 (2003): 95-125.

Grotius, Hugo. On the Law of War and Peace. Edited by Stephen C. Neff. Cambridge: Cambridge University Press, 2012.

Jolley, Nicholas. Locke: His Philosophical Thought. Oxford: Oxford University Press, 1999.

Law, Edmund. 'A Defence of Mr. Locke's Opinion Concerning Personal Identity'. In vol. 2 of The Works of John Locke. 12th ed. London: Rivington, 1824.

Locke, John. An Essay concerning Human Understanding. Edited by Peter H. Nidditch. Oxford: Clarendon Press, 1975.

Locke, John. Political Essays. Edited by Mark Goldie. Cambridge: Cambridge University Press, 1997.

Locke, John. Two Treatises of Government. Edited by Peter Laslett. Cambridge: Cambridge University Press, 1988.

Locke, John. Writings on Religion. Edited by Victor Nuovo. Oxford: Clarendon Press, 2002.

LoLordo, Antonia. 'Author Meets Critics on Antonia LoLordo's "Locke's Moral Man": LoLordo's Reply to Weinberg', The Mod Squad: A Group Blog in Modern Philosophy, June 25, 2014, http://philosophymodsquad.wordpress.com/2013/07/07/amc-lmmlolordos-reply-to-weinberg/.

LoLordo, Antonia. Locke's Moral Man. Oxford: Oxford University Press, 2012.

LoLordo, Antonia. 'Three Problems in Locke's Ontology of Substance and Mode'. In Contemporary Perspectives on Early Modern Philosophy: Nature and Norms in Thought, edited by Martin Lenz and Anik Waldow. Dordrecht: Springer, 2013, 51-64.

Lowe, E. J. Locke on Human Understanding. Abingdon, Oxon: Routledge, 1995.

Mackie, J. L. Problems from Locke. Oxford: Clarendon Press, 1976.

Matthews, Eric. 'Descartes and Locke on the Concept of a Person', The Locke Newsletter 8 (1977): 9-34.

Mautner, Thomas. 'Locke's Own', The Locke Newsletter 22 (1991), 7380. 
Olivecrona, Karl. 'Appropriation in the State of Nature: Locke on the Origin of Property', Journal of the History of Ideas 35 (1974): 211-30.

Olivecrona, Karl. 'Locke's Theory of Appropriation', The Philosophical Quarterly 24 (1974), 220-34.

Noonan, Harold W. Personal Identity. 2nd ed. Abingdon, Oxon: Routledge, 2003.

Parfit, Derek. Reasons and Persons. Oxford: Clarendon Press, 1984.

Pufendorf, Samuel. Of the Law of Nature and Nations. Translated by Basil

Kennett and George Carew, edited by Jean Barbeyrac. London: Printed for J. Walthoe, R. Wilkin, J. and J. Bonwicke, S. Birt, T. Ward, and T. Osborne, 1729.

Reid, Thomas. Essays on the Intellectual Powers of Man. Edited by Derek

R. Brookes. Edinburgh: Edinburgh University Press, 2002.

Schechtman, Marya. The Constitution of Selves. Ithaca: Cornell University Press, 1996.

Spector, Jessica. 'The Grounds of Moral Agency: Locke's Account of Personal Identity', Journal of Moral Philosophy 5 (2008): 256-81.

Stanton, Timothy. 'Christian Foundations; or Some Loose Stones? Toleration and the Philosophy of Locke's Politics'. Critical Review of International Social and Political Philosophy 14 (2011): 323-47.

Strawson, Galen. Locke on Personal Identity: Consciousness and Concernment. Princeton: Princeton University Press, 2011.

Stuart, Matthew. Locke's Metaphysics. Oxford: Oxford University Press, 2013.

Thiel, Udo. Lockes Theorie der personalen Identität. Bonn: Bouvier Verlag, 1983.

Thiel, Udo. The Early Modern Subject: Self-Consciousness and Personal Identity from Descartes to Hume. Oxford: Oxford University Press, 2011.

Tully, James. A Discourse on Property: Locke and his Adversaries. Cambridge: Cambridge University Press, 1980.

Weinberg, Shelley. 'Author Meets Critics on Antonia LoLordo's "Locke's Moral Man": Shelley Weinberg', The Mod Squad: A Group Blog in Modern Philosophy, June 25, 2014, http://philosophymodsquad.wordpress.com/2013/07/06/amc-lmmshelley-weinberg/.

Weinberg, Shelley. 'Locke on Personal Identity', Philosophy Compass 6 (2011): 398-407.

Weinberg, Shelley. 'The Coherence of Consciousness in Locke's Essay', History of Philosophy Quarterly 25 (2008): 21-39.

Weinberg, Shelley. 'The Metaphysical Fact of Consciousness in Locke's Theory of Personal Identity', Journal of the History of Philosophy, 50 (2012): 387-415 
Winkler, Kenneth P. 'Locke on Personal Identity', Journal of the History of Philosophy 29 (1991): 201-26.

Yaffe, Gideon. 'Locke on Ideas of Identity and Diversity'. In The Cambridge Companion to Locke's "Essay concerning Human Understanding", edited by Lex Newman. Cambridge: Cambridge University Press, 2007, 192-230.

Yolton, John W. Locke: An Introduction. Oxford: Basil Blackwell, 1985.

Zack, Naomi. 'Locke's Identity Meaning of Ownership', The Locke Newsletter 23 (1992): 105-13. 